\title{
3 FREEDOM OF, FROM OR FOR RELIGION: PERSPECTIVES FROM PROSCRIPTION OF RELIGIOUS ACTIVITIES IN HALLS OF RESIDENCE AT OBAFEMI AWOLOWO UNIVERSITY, ILE-IFE, NIGERIA
}

\section{Omomayowa O. Abati ${ }^{1}$ Ebenezer O. Elesemoyo}

\section{INTRODUCTION}

The debate over how religious expressions should be managed in public space continues to receive significant attention in both academic and public discourses. The forms these expressions take vary from country to country. As such, the debates give rise to different results and consequences. ${ }^{3}$ In Nigeria, controversies about religious expression in education space have taken two major forms. First is the controversy over the wearing of Muslim headscarf in schools. Recently, in selected schools in Lagos, ${ }^{4}$ Osun ${ }^{5}$ and $\mathrm{Oyo}^{6}$ states, controversies ensued over the wearing of Muslim headscarf as part of school uniform. While the cases in Lagos and Osun occurred at public schools, the Oyo case was in a private school. The Lagos and Osun cases were addressed through litigation, ${ }^{7}$ that of Osun attracting significant attention, owing to the reaction of students at a public secondary school in Iwo town. In protest of the State High Court ruling that the Muslim students had a right to wear the hijab as part of their school uniform, ${ }^{8}$ other students came to the school in church robes and traditional priestly regalia to protest the decision. ${ }^{9}$ At the root of the contention are differing claims to religious freedom. ${ }^{10}$

1 Graduate student, Department of Political Science, Obafemi Awolowo University, Nigeria.

2 Undergraduate student, Department of Religious Studies, Obafemi Awolowo University, Nigeria.

3 Welch T. 2007. "The Prohibition of the Muslim Headscarf: Contrasting International Approaches in Policy and Law", Denning Law Journal 19:181-217.

4 Ramon O. 2017. "Lagos Takes Hijab Case to Supreme Court”, Punch, 7 February.

5 Editorial. 2016. "Hijab in Osun Schools”, Daily Trust, 20 June; Makinde F. 2016 "Hijab: Mortgaging Osun Pupils' Future with Religious Animosity", Punch, 25 June.

6 Soyombo F. 2018. "That Hijab Controversy Raging in UI's International School”, Sahara Reporters, 19 November; Akinpelu Y. 2018. "Hijab Controversy: UI International School to Resume Monday", Premium Times, 25 November; Babalola A. 2018. "Muslim Parents Disagree over UI Secondary School's Hijab Controversy", Punch, 14 November.

7 Oladimeji R. 2016. “Lagos Takes Hijab Case to Supreme Court”, Punch, 7 February.

8 Makinde F. "Breaking: Osun Students Can Wear Hijab to School - Court”, Punch, 3 June.

9 Information Nigeria. 2016. "CAN threatens Showdown in Osun Over Judgment Permitting Hijab In Schools"; Akinnaso N. 2016. "Osun 'Hijab' Crisis with Statistics”, Punch, 5 July.

10 Oba A. 2009. "The Hijab in Educational Institutions and Human Rights: Perspectives from Nigeria and Beyond", Identity, Culture E Politics: An Afro-Asian Dialogue 10(1):51-74. 
Second, and the focus of this chapter, is the challenge of managing sound disturbances emanating from religious houses. The scale here is broader, considering that Nigeria is adjudged to have the largest number of churches per capita in the world. ${ }^{11}$ It is even hinted that on a street of four kilometres stretch, no fewer than fifty different religious buildings can be sighted, ${ }^{12}$ and because proactive measures are not taken to ensure religious buildings are constructed in accordance to acoustic requirements and in compliance with noise threshold levels, ${ }^{13}$ residents are subjected to intolerable sound disturbances. With the use of public address systems (PAS), religious houses extend their sonic boundaries far beyond the confines of their religious buildings, without regard for day or night. This has earned the attendant religious sound disturbance the appellation of a "silent killer". ${ }^{14}$

The appellation is not misplaced, considering that there is increasing scientific evidence linking prolonged exposure to sound disturbance directly with sleep disorders $^{15}$ and indirectly with cardiovascular diseases, ${ }^{16}$ cognitive impairment, mental and emotional disorders. ${ }^{17}$ The World Health Organization (WHO), in a quantitative risk assessment of environmental noise in Western Europe, estimated that "one million healthy life years are lost every year from traffic-related noise [alone] in the sub-region". ${ }^{18}$ Worst still, is the effect on cognitive development. Studies have identified exposure to sound disturbance in school environment as a major contributor to low cognitive ability amongst students, and evidence suggests that the effects are more pronounced in children compared to adults. ${ }^{19}$

11 Adesanya IO. 2011. "Environmental Effects of Church Proliferation: The Redeemed Christian Church of God as a Case Study", International Journal of Humanities and Social Science 1(15):177-182.

12 Adesanya, "Environmental Effects of Church Proliferation".

13 Noise levels are measured in decibels $(\mathrm{dB})$. One decibel equals one measure of hearing and $60 \mathrm{~dB}$ is adjudged the level of normal talking. However, WHO specifies that the permissible noise level in an educational environment should not exceed $35 \mathrm{~dB}$, and exposure for more than six hours a day to sound in excess of $85 \mathrm{~dB}$ is regarded as potentially hazardous to human health.

14 Adeyemi-Kayne OI. 2017. “Turn Down the Noise: The Effect of Noise Pollution in Lagos State", video documentary by the State Environment Protection Agency.

15 World Health Organization (WHO). 2011. Burden of Disease from Environmental Noise: Quantification of Healthy Life Years lost in Europe. Bonn: World Health Organization (WHO) European Centre for Environment and Health.

16 Munzel T, Schimdt FP, Steven S, Herzog J, Daiber A and Sorensen M. 2018. “Environmental Noise and the Cardiovascular System", Journal of American College of Cardiology 71(6): 688-697.

$17 \mathrm{WHO}$, Burden of Disease from Environmental Noise.

$18 \mathrm{WHO}$, Burden of Disease from Environmental Noise.

19 See Gilavand A and Jamishidnezhad A. 2016. “The Effect of Noise in Educational Institutions of Learning and Academic Achievement of Elementary Students in Ahaz, South-west of Iran", International Journal of Paediatrics 4(3)1453-1463; Ana GE, Shendell DG, Brown GE and Sridhar MKC. 2009. "Assessment of Noise and Associated Health Impacts at Selected Secondary Schools in Ibadan, Nigeria", Journal of Environmental and Public Health. https://doi.org/10.1155/2009/739502 
As such, states and non-state actors across developed and developing nations have begun to take regulatory actions to curb the menace of sound disturbance. ${ }^{20}$ Despite the severity of the negative evidential effect of sound disturbance for human well-being, regulatory actions taken against religious institutions as one of the contributors are often received contentiously..$^{21}$ This is not surprising after all, given the central role religion plays in both social organisation and the consciousness of Nigerians. In a 2010 survey, ${ }^{22} 87 \%$ of Nigerians see themselves as "deeply committed to the practices and tenets of Christianity or Islam", and an earlier survey ${ }^{23}$ showed $^{2}$ that $85 \%$ of Nigerians trusted religious leaders and were willing to give them more powers. Hence, religion is not just a private issue for Nigerians, but it also plays a significant role in the public domain. Hence, it is argued that all individuals live in the sphere of two sets of norms - secular and sacred. ${ }^{24}$ Drawing the line of demarcation between these "two publics" can be very complex and controversial, especially in a plural context like a higher education institution. ${ }^{25}$

At the heart of this controversy is a subtle contention over the model of religious freedom - freedom of, from or for religion - that will ensure acceptable expression of religion in public spaces within plural societies. The issues involved are complex and cannot be exhaustively discussed here. Thus, in this chapter, we focus our lens on a micro instance of the controversy arising from regulation of religious sound, which led to the proscription of religious activities in students' halls of residence at Obafemi Awolowo University (OAU) in Nigeria. The OAU scenario presents a micro-level instance of the concerns expressed across Nigeria about the menace of sound disturbances emanating from religious institutions. Thus, this case study provides an analytical insight into the challenges involved in managing religious expression in Nigeria higher education contexts. We explore how religious sound disturbance is negotiating the boundary of religious freedom in a higher education institution. Specifically, we examine the nature, periodicity and temporality of religious activities and religious sound in the university?

20 World Health Organization (WHO). 2010. Parma Declaration on Environment and Health and Commitment to Act. Copenhagen: WHO Regional Office for Europe; World Health Organization (WHO). 2009. Night Noise Guidelines for Europe. Copenhagen: WHO Regional Office for Europe.

21 Chikelu C. 2017. "Desist from Public Disturbance, AEPB Appeals to Religious Houses". Premium Times, 9 September; Alao T, Badejo E and Chukwu L. 2015. "Controversy Trails Implementation of Noise Pollution Law in Lagos", The Guardian, 22 January.

22 Pew Forum on Religion \& Public Life. 2010. Tolerance and Tension: Islam and Christianity in Sub-Saharan Africa. Washington, DC: Pew Research Center.

23 Ferrett G. 2015. "Africans Trust Religious Leaders", BBC, 14 September.

24 See Kiviorg M. 2011. Freedom of Religion or Belief: The Quest for Religious Autonomy, PhD diss, University of Oxford; Safran W (ed). 2003. The Secular and the Sacred: Nation, Religion and Politics. Great Britain: Frank Cass \& Co Ltd.

25 Russo CJ. 2015. "Religious Freedom in Education: A Fundamental Human Right", Religion E Education", 42(1):17-33. 
In order to do this, we proceed by highlighting the main contentions over the boundaries of religious freedom in higher education space, and then discuss the regulatory frameworks for sound disturbance in the higher education context. Further to this, we justify our research context by examining the politics of religion at $\mathrm{OAU}$, before describing our research methods. Using the findings from survey, key informant interviews and participant observation, we discuss the normative implications of the various models of religious freedom while advancing freedom for religion as the model suited for plural contexts.

\section{CONTENTIONS OVER BOUNDARIES OF RELIGIOUS FREEDOM IN HIGHER EDUCATION SPACE}

The argument over the role that religion should play in an educational institution has recently tilted towards the broader debate of "culture wars". ${ }^{26}$ In this sense, dissenting views of religious freedom are projected within Higher Education Institutions (HEIs), echoing what the historians Roger Chapman and James Ciment mean when they asserted that a culture war occurs "when different stories clash and compete for public acceptance". ${ }^{27}$ The dissenting voices stand as proxy for conflict between "the sacred" and "the secular" - where any decision to demarcate religion from education is regarded as secularist by one end and sacrilegious by the other. ${ }^{28}$ At the heart of this dichotomy are the forces of push and pull inherent in the models of religious freedom - freedom of, from and for religion. Of the three, freedom of religion is the most used and, as such, has become fluid in its meaning and scope over the years. The general understanding is that freedom of religion connotes the guarantee that "religious communities and their adherent [can] be ultimately committed to an absolute authority beyond the relative authority of the state". ${ }^{29}$ In essence, it is a fundamental human right intended to enable religious adherents to practise their religion without interference from state or individuals.

But with the rise of secularism around the world freedom of religion has acquired additional meaning, whereby it is understood to entail freedom from religion. For proponents of this expansion, it is argued that the right that guarantees free exercise

26 Withrow B. 2017. "How Religious Fear is Shaping the Culture War", The Daily Beast, 10 December; Doty DS. 2008. "The Road Less Travelled: Using Board Policy and Accommodation Strategies to Peacefully Resolve Religious Disputes in Public Schools", in Soronen L (ed). Religion and Public Schools: Striking A Constitutional Balance. Alexandria, VA: National School Board Association (NSBA).

27 Chapman R and Ciment J (eds). 2013. Culture Wars in America: An Encyclopaedia of Issues, Viewooints, and Voices. London: Routledge.

28 Safran W (ed). 2005. The Secular and the Sacred: Nation, religion and Politics. Portland, OR: Frank Cass Publishers.

29 Scharffs BG, Moaz A and Wooley AI. 2019. "Introduction: Freedom of/for/from/within religion: conceptually inseparable rights", in Scharffs BG, Moaz A and Wooley (eds). Religious Freedom and the Law: Emerging Contexts for Freedom for and From Religion. New York: Routledge, Taylor and Francis Group, 1-11. 
of religion necessarily guarantees free exercise of non-religion. ${ }^{30}$ In other words, the freedom to believe carries with it the freedom not to believe. In this sense, freedom from religion treats religion as a negative phenomenon that needs to be separated from freedom, in a manner similar to the separation between religion and state. ${ }^{31}$ Here, it is suggested that for freedom to be attained, it must be severed from the corrupting influence of religion. But this is where it differs from freedom of religion, prompting some scholars to argue that freedom from religion cannot be said to be contained in the notion of freedom of religion. ${ }^{32}$ Thus, while freedom of religion treats freedom is a necessary condition of the protection of religion, the freedom from religion view does not see religion as something that needs protection, but rather as something from which freedom needs to be protected. These two notions are opposite, and they cannot possibly be contained in one model. ${ }^{33}$

To treat religion as a negative phenomenon as freedom from religion does, is to deny the positive influence of religion in both individual and public life. Here is where the proponents of freedom for religion advocate for more than the subtle protection of religion that is provided for in the model of freedom of religion and for a stronger protection of religion for individual and public flourishing. Their argument hinges not just on the moral contribution of religion to society, but also its positive effect on individual and society well-being. ${ }^{34}$ This is well supported in literature, with evidence linking participation in religion services to reduced mortality, ${ }^{35}$ improved physical and mental health, ${ }^{36}$ better social relationships ${ }^{37}$ and general life satisfaction. ${ }^{38}$ And if well-being of the people is a major preoccupation of the state, then it is only logical that the state has special reason to, at least, remove

30 Sullivan K. 1992. "Religion and Liberal Democracy", University of Chicago Law Review 59:195-223; Cook KA. 2000. "Abortion, Capital Punishment, and The Politics of 'God's Will"', William and Mary Bill of Rights Journal 9(1):105-136.

31 Hamburger P. 2002. Separation of Church and State. Cambridge, MA: Harvard University Press.

32 Sapir G and Statman D. 2005. "Why Freedom of Religion Does Not Include Freedom from Religion", Law and Philosophy 24(5):467-508. Sapir and Statman, "Why Freedom of Religion Does Not Include Freedom from Religion”. VanderWeele TJ. 2017. "Religious Communities and Human Flourishing", Current Directions in Psychological Science 26(5):476-481.

Hayward RD and Elliott M. 2014. "Cross-national analysis of the influence of cultural norms and government restrictions on the relationship between religion and well-being", Review of Religious Research 56:23-43; VanderWeele TJ. 2017. "Religion and health: A synthesis", in Peteet JR and Balboni MJ (eds). Spirituality and religion within the culture of medicine: From evidence to practice. New York: Oxford University Press, 357-401.

36 VanderWeele TJ, Li S, Tsai A and Kawachi I. 2016. "Association Between Religious Service Attendance and Lower Suicide Rates among US Women", JAMA Psychiatry 73:845-851.

37 Li S, Kubzansky LD and VanderWeele TJ. 2016. "Religious Service Attendance, Divorce, And Remarriage Among US Women”, PLoS One 13(12):e0207778.

38 Lim C and Putnam RD. 2010. "Religion, social networks, and life satisfaction", American Sociological Review 75:914-933. 
limitations on religion and to, at best, ensure its promotion in order not to lose one of the strongest sources of happiness for its people.

In the Nigerian legal framework, similar contentions are inherent in the provisions of Section 38 (Subsections 1, 2 and 3) ${ }^{39}$ of the 1999 Constitution. While Subsection 1 provides a general protection of the freedom of religion, Subsections 2 and 3 qualify this protection further, resulting in some contradictions. The issue of faith-based HEIs helps to highlight the contradiction. Contrary to the protection that Subsection 2 grants against anyone being compelled to partake of a religious observance other than his own religion, there are reports that faith-based HEIs compel students to worship only in their denominational congregation, making it impracticable for students with differing religious affiliations to practise their religion, let alone form religious associations for observance of their religious practices. ${ }^{40}$ The contradiction is in the use of the phrase "any place of education" in both Subsections 2 and 3. While Subsection 2 includes faith-based HEIs amongst the places of education, such that no student can be compelled to take part in religious ceremony other than his own or not approved by his parent, Subsection 3 asserts the contrary, granting religious communities the power to compel students in their religious practise on the condition that the place of education is maintained wholly by them.

The students at faith-based HEIs are required to declare their religious affiliation during the process of admission and compelled to sign an agreement of undertaken to attend all the religious observances of the institution, with strict attendance policies which are used as prerequisite qualification for entry into the examination hall at the end of each semester. ${ }^{41}$ These practices have seen members of alternative religions denied admission into faith-based HEIs where they do not share the dominant faith. ${ }^{42}$ This practice violates both the freedom of religion and freedom from religion of the students. Though it may be argued that it affords students whose religious affiliation aligns with that of the faith-based HEIs the exercise

39 Constitution of the Federal Republic of Nigeria, sec 38(1): “Every person shall be entitled to freedom of thought, conscience and religion, including freedom to change his religion or belief, and freedom (either alone or in community with others, and in public or in private) to manifest and propagate his religion or belief in worship, teaching, practice and observance. (2) No person attending any place of education shall be required to receive religious instruction or to take part in or attend any religious ceremony or observance if such instruction, ceremony or observance relates to a religion other than his own, or religion not approved by his parent or guardian. (3) No religious community or denomination shall be prevented from providing religious instruction for pupils of that community or denomination in any place of education maintained wholly by that community or denomination."

40 Ogun F. 2017. "Illegality of Covenant University Students' Suspension by School Management", The Guardian, 16 May.

41 Ogun, "Illegality of Covenant University Students' Suspension by School Management".

42 Omoyele O. 2013. “Broken Covenant - Bishop Oyedepo's University Denies Student Admission Because He's a Muslim", The Premier, 26 February. 
of their religious devotion, even so, it equally deprives them of the free will that freedom of religion supposedly guarantees by attaching an attendance policy to the exercise of their right. Worse still, for students of alternative faith, it not only violates their freedom to practise their religion, but also their right not to be coerced into observing a religious practice that is against their conscience.

In the OAU case at hand, students are not coerced into an institutionally-established religious observance, yet expressions of varying religious practices are in sonic competition for space. While some religious students contend that they have the freedom to exercise their religion at whatever time they wish, and in whatever mode they prefer, non-religious students contend that this expression of religious freedom violate their own right to enjoy the shared space without any form of disturbance. It is necessary therefore to examine the regulatory framework for sound disturbances at both the state and educational institution levels.

\section{REGULATORY FRAMEWORK FOR SOUND DISTURBANCE IN NIGERIA}

\section{National and state level regulations}

Though the Nigerian Constitution does not stipulate any regulation of sound disturbance, agencies have been set up by acts of parliament at both the federal and subnational levels recommending minimum threshold of sound disturbances in public spaces, especially educational institutions. For instance, the act establishing the National Environmental Standards and Regulations Enforcement Agency (NESREA) empowers the agency to make regulations on environmental challenges, including noise standards and control. ${ }^{43}$ Similarly, at the subnational level, government agencies have been established with powers to manage sound disturbance within their geographical jurisdiction. For example, the law establishing the Lagos State Environmental Protection Agency (LASEPA) empowers it to make regulations on "acceptable standards or criteria to control the pollution level of water, air, noise and land in consonance with the Federal Government guidelines and policies and criteria on the environment". ${ }^{44}$ In this vein, the National Environment (Noise Standards and Control) Regulations and LASEPA Environmental Noise Standards and Control stipulates that maximum permissible noise levels for "any building used as hospital, convalescence home, home for aged, sanatorium and institutions of higher learning, conference rooms, public library, environmental or recreational sites shall not be more than $45 \mathrm{~dB}$ in the day and not more than $35 \mathrm{~dB}$ at night". ${ }^{45}$

43 National Environmental Standards and Regulations Enforcement Agency Act, 2007.

44 Lagos State Environmental Protection Agency Law, 2014, sec 35.

45 National Environmental Standards and Regulations Enforcement Agency Act. 2007; Lagos State Environmental Protection Agency Law, 2014, sec 35. 


\section{Higher education institution regulations}

The higher education institutions (HEI) in Nigeria are autonomous and independently operated by their individual governing councils and the university senate committees. As such, each university has regulations and agencies operating to complement the national and subnational regulatory frameworks within the context of its peculiarity and autonomy. At Obafemi Awolowo University $(\mathrm{OAU})$, the agency responsible for the management of all student concerns is the Division of Student Affairs (DSA). Headed by a dean who is appointed by the vice chancellor $(\mathrm{VC})$ and directly responsible to the VC's office, the DSA ensures proper atmosphere and good interpersonal relationships that are essential for students' overall social and academic welfare. Included amongst the responsibilities of the DSA is the management of the halls of residence, the registration of all studentbased organisations on campus, including religious organisations, and overseeing of student union representatives.

The DSA annually publishes the Student Handbook Manual, which details the regulatory framework for all university-student relational affairs. However, there is no specific indication in the handbook of acceptable religious practices within the student residential halls. Mention is made of permission to hold unspecified "meetings" and "parties" within the halls. ${ }^{46}$ The Student Handbook stipulates that "written permission must be obtained from the hall warden" in reply to "an application in writing" earlier made by the concerned group before such meetings and parties can hold. ${ }^{47}$ It is within the purview of this provision that religious organisations conduct services and meetings within the available spaces in the halls of residences. Also, the DSA has at different times allocated rooms not use to religious bodies, such as secretariats, mosque and offices, which the religious bodies in turn use for meetings, musical rehearsals, prayer vigils and other activities.

The provisions of the handbook and the allocations of hall spaces appears to show that the university is not averse to the conduct of religious activities in the halls, yet the activities were considered to have overstepped the limit of the regulatory boundaries for religious bodies. This brings to the fore the contradiction between what the rule book permits and what is actually permitted in practice. Furthermore, the handbook permits "parties" to extend their sound disturbance to as far as "twelve midnight" ${ }^{48}$ This, therefore, confirms further the regulatory contradiction which has left a lacuna for dissenting conducts amongst religious devotees within the residential halls.

46 Student Handbook. 2017. Division of Student Affairs Student General Information for 2016/2017 Academic Session. Ile-Ife: Obafemi Awolowo University Press.

47 Student Handbook. Division of Student Affairs Student General Information for 2016/2017 Academic Session. 


\section{RESEARCH CONTEXT AND METHODOLOGY}

\section{The politics of religion at Obafemi Awolowo University}

The dominant religions at OAU are Christianity and Islam, though there are some people who practise traditional indigenous religions and an undetermined number of non-religious. This mirrors the religious demography of the country and, as such, is a microcosm of the prevailing religious politics. ${ }^{49}$ Religion also occupies an important space in the realm of affairs in OAU. While this should not necessarily portend any concern for peaceful coexistence amongst members of the university community, recent events at the university have cast doubt on this presupposition.

In the 2005/2006 academic session, the university was closed as a result of conflict between Muslim students and secularist students of the Awolowo Hall. The conflict, which was later dubbed the mojo ${ }^{50}$ strike, broke out over the viewing of pornography contents in the hall's common room by some groups of students. While secular students claimed that no regulation prohibited the viewing of such content in the hall common room, Muslim students disputed it, because it was too close to their mosque and, as such, constituted an offense against their members, especially the females.

While a repeat of such conflicts has not been witnessed recently, milder disagreements have emerged over the issue of religious sound disturbances emanating from the proliferation of religious activities in the residential halls. The complaints are targeted at the periodicity and temporality of the religious activities and its attendant sound disturbance. The complaint may be justifiable considering that the university currently has over one hundred registered clubs and societies, which are in symbolic competing for space and sonic presence within the campus. New ones are continually springing up, many still unregistered, ${ }^{51}$ of which a large portion are religious organisations. ${ }^{52}$

Given this plethora of religious organisations operating within the university, most available spaces, including classrooms, open and covered sport and recreational spaces, are used as religious worship centres, with the halls of residence not spared.

49 It is difficult to situate Nigeria on the secular versus non-secular spectrum either as a secular state or as a non-secular state. See Sampson TI. 2014. "Religion and the Nigerian State: Situating the de facto and de jure frontiers of State-Religion Relations and its implications for National Security", Oxford Journal of Law and Religion 3(2):311-339.

50 A local parlance for pornographic content, especially audio-visual types.

51 Unregistered here is intended to capture both the associations that have applied for registration but are pending approval, and the associations that have not even made an attempt to register with the Division of Student Affairs. Thus, it is difficult to accurately quantify the number of religious organisations currently operating on the university campus.

52 Student Handbook. Division of Student Affairs Student General Information for 2016/2017 Academic Session, 31. 
Consequently, the nine student halls of residence within the university - Awolowo, Fajuyi, Education Trust Fund (ETF), Moremi, Akintola, Alumni, Angola, Murtala Muhammed and Mozambique - have been designated as worship centres. Eight of the nine halls, four female and four male, are occupied by undergraduate students, divided along gender. Also, amongst them are Angola (male) and Mozambique (female) halls which are designated for fresh undergraduate students only. The only postgraduate hall, Murtala Muhammed, is occupied by both female and male postgraduate students.

Responding to complaints, the university management has prohibited the use of sport, recreational classrooms and academic facilities and halls of residence for all forms of religious activities. To ensure effectiveness of the policy, the university began allocating land to religious bodies as worship centres at a designated distant location within the university premises, known as the Religion Ground, ${ }^{53}$ after fulfilment of certain specified conditions by the religious bodies. ${ }^{54}$ However, given that not all registered religious bodies could be allocated portions of land for worship, significant numbers of religious activities are still held in the student halls of residence. These activities cannot occur without disturbing the hall residents, creating a problem that has resulted in the clampdown on religious activities within the student halls of residence by the university.

\section{Methodology of the instant study}

Given that the halls of residence are variously susceptible to religious activities going by the availability of spaces for religious worship, five halls ${ }^{55}$ were purposively selected - Awolowo, Fajuyi, Moremi, Akintola and Murtala halls - representing four undergraduate halls (two male and two female) and one postgraduate hall, respectively. The average population of each hall was estimated at about 1,400 student residents per hall, bringing the total population of the study area to about 10,000 residents. A sample of 350 residents was selected across the halls,

53 Some portion of university land designated for religious purposes. This is properly delineated in the school master plan. The intention is to remove religious activities far from academic activities to avoid conflict of purpose and for avoidance of sound disturbances. Within the Religion Ground, a crusade site is also earmarked and used to host prominent Nigerian pastors for revival crusades.

54 For a religious body to be allocated a portion of land in the Religion Ground, it must apply for a fellowship, submitting a proposed building design and financial budget, supported by its parent religious body. The reason for requesting for the support of their parent body is both to guarantee the credibility and accountability of the religious organisation, as well as to determine the financial viability of building the approved structure.

55 Though Angola and Mozambique halls are also highly susceptible to religious noise, they were not included, because the 100 level students residing in the halls at the time of the study resumed in the $2017 / 2018$ academic session, but proscription was enforced during the $2015 / 2016$ academic session. Thus, it was considered that they would not be able to provide informed opinions on the matter. 
with 70 respondents per hall. ${ }^{56}$ A two-page questionnaire was administered to the respondents, eliciting their perception of the proscription of religious activities within the halls. As well, eight university officers and student representatives were interviewed for their views of the justification of the university decision to proscribe religious activities in the halls of residence. The eight key respondents interviewed included: the dean of the Division of Student Affairs (DSA); the chief imam of OAU Central Mosque; the president of OAU Muslim Student Society of Nigeria (MSSN); the president of OAU Joint Christian Mission (UJCM), an interdenominational umbrella organisation for Christian students; the chairman of the OAU Christian Mobilization Committee, an interdenominational umbrella for Christian university staff; and one hall warden each from the postgraduate hall, a female and a male undergraduate halls of residence.

\section{FINDINGS AND DISCUSSION}

\section{Sound disturbance as the rationale for the proscription}

Contrary to newspaper reports in the inception of the proscription, ${ }^{57}$ we ascertained that sound disturbance was the major reason for the proscription of religious activities in the halls of residence. The dean of the Division of Student Affairs (DSA) confirmed that the action of the university was "remotely in response to complaints about religious disturbances in the form of noise". ${ }^{58}$ Though, in his view, the immediate cause of the decision was the "proven investigation into allegations of unauthorised conversion of space ${ }^{59}$ and illegal harbouring ${ }^{60}$ of students in the allocated spaces for religious bodies which was reported amongst the Islamic organisations", ${ }^{61}$ but which the MSSN president vehemently denied, explaining that "the scarcity of student accommodation spaces necessitated the conversion of some of the allocated worship spaces to residential rooms for members", especially female members. ${ }^{62}$ Guardian, 18 June; Editorial. 2016. "OAU's Timely Response to Religious Extremism", Nigerian Tribune, 12 September; Editorial. 2017. "Group Alarms over Looming Religion Crisis, Threat to Peace in OAU", African Examiner, 23 February.

58 Interview with the dean, Division of Student Affairs (DSA), by the authors, Obafemi Awolowo University, Ile-Ife, Nigeria, 30 March 2018.

59 This refers to the use of an allocated space for purpose(s) other than for which it was initially allocated.

60 This refers to an unauthorised accommodation of a person (student or non-student) in the dormitory of a student hall of residence by a legally accommodated student.

61 Interview with the dean, DSA, OAU.

62 Interview with a one-time president of the Muslim Student Society of Nigeria (MSSN), Obafemi Awolowo University, Ile-Ife, Nigeria, by the authors, Sport Complex, 6 March 2018. 
Corroboratively, the survey responses in Table 3.1 also showed that noise/sound disturbances (4.0), unauthorised conversion of space (3.6) and illegal harbouring (3.5) ranked the highest and above the average (2.3), indicating that they were the major factors which the respondents perceived as the reasons why religious activities were proscribed within the halls of residence. On the other hand, immorality, intrareligious and interreligious intolerances, which were the images depicted by the headlines of most newspaper reports ${ }^{63}$ on the proscription, were the least perceived reasons for the proscription, with mean scores of 1.7 each.

Table 3.1: Residents' perception on rationale for proscription of religious activities

\begin{tabular}{|c|c|c|c|c|c|c|}
\hline REASONS & MEAN & $\begin{array}{c}\text { STRONGLY } \\
\text { DISAGREE } \\
(\%)\end{array}$ & $\begin{array}{c}\text { DISAGREE } \\
(\%)\end{array}$ & $\begin{array}{c}\text { NEUTRAL } \\
(\%)\end{array}$ & $\begin{array}{c}\text { AgREE } \\
(\%)\end{array}$ & $\begin{array}{c}\text { STRONGLY } \\
\text { AGREE } \\
(\%)\end{array}$ \\
\hline Noise & 4.0 & 0.6 & 2.6 & 24.0 & 39.4 & 33.4 \\
\hline Conversion of space & 3.6 & 3.1 & 12.9 & 14.3 & 64.0 & 5.7 \\
\hline Illegal harbouring & 3.5 & 9.1 & 22.9 & 12.3 & 24.0 & 31.7 \\
\hline Leadership tussle & 2.0 & 35.1 & 47.1 & 4.9 & 8.6 & 4.3 \\
\hline Infighting & 1.9 & 37.4 & 45.4 & 5.1 & 10.6 & 1.4 \\
\hline Misappropriation & 1.8 & 39.4 & 50.6 & 4.9 & 4.6 & 0.6 \\
\hline Interreligious & 1.7 & 40.3 & 50.6 & 6.0 & 2.6 & 0.6 \\
\hline Intra-religious & 1.7 & 40.9 & 51.4 & 6.3 & 1.1 & 0.3 \\
\hline Immorality & 1.7 & 64.6 & 20.0 & 1.1 & 11.1 & 3.1 \\
\hline No justifiable reason & 1.5 & 77.1 & 8.0 & 1.1 & 12.0 & 1.7 \\
\hline Aggregate mean & 2.3 & & & & & \\
\hline
\end{tabular}

Source: The authors' fieldwork, 2018

The nature, periodicity and temporality of religious activities and sound disturbances

Contestation between the Christians and Muslims has been observed over the level of contribution to sound disturbance. While the president of the University Joint Christian Mission (UJCM) acknowledges that "it is possible to associate Christian worship services in the halls of residence with sound disturbances", ${ }^{64}$ a one-time president of the OAU Muslim Student Society of Nigeria (MSSN) maintains that "noise cannot be associated with the practice of Islam within the halls of residence", ${ }^{65}$ because even when they use public address systems (PAS) they "only

63 Editorials: "Before Religion Derails OAU", "OAU's Timely Response to Religious Extremism", and "Group Alarms over Looming Religion Crisis, Threat to Peace in OAU".

64 Interview with the president, University Joint Christian Movement (UJCM), Obafemi Awolowo University, Ile-Ife, Nigeria, by the authors, Geology Car Park, 6 March 2018.

65 Interview with a one-time president of the MSSN, OAU. 
make use of it [PAS] when it is time to call members for prayers which doesn't last more than a few minutes" ${ }^{66}$

The survey responses equally mirror this contestation with respect to the nature of the specific religious activities, the periodicity of their occurrence and the temporality of consequential sound disturbance. In Table 3.2, most respondents reported that Sunday worship service (85\%) and mid-week worship service (81\%) were the most frequently occurring religious activities witnessed within the halls of residence. These were followed by morning cry ${ }^{67}(72 \%)$ and Muslim call to prayer $(67 \%)$, while subgroup meetings (45\%), room fellowship (41\%) and executive meetings (39\%) were the least reported religious activities. This result follows the logic that Sunday worship service, mid-week service, morning cry and Muslim call to prayer are easily noticeable, because these type of religious activities are projected with aid of a PAS, mostly to "call attention of 'docile' worshippers" as remarked by the president of UJCM. ${ }^{68}$ On the other hand, room fellowship, subgroup meetings and executive meetings do not require a PAS call, since they are gatherings of only a few members. Thus, these activities are not considered a major source of sound disturbances in the residential halls.

Table 3.2: Nature of religious activities practised in the halls of residence

\begin{tabular}{|l|c|c|c|c|c|c|c|}
\hline Religious ACtIVITIES & MeAN & $\begin{array}{c}\text { PG } \\
(\%)\end{array}$ & $\begin{array}{c}\text { AwOLOWO } \\
(\%)\end{array}$ & $\begin{array}{c}\text { FAJUYI } \\
(\%)\end{array}$ & $\begin{array}{c}\text { MOREMI } \\
(\%)\end{array}$ & $\begin{array}{c}\text { AKINTOLA } \\
(\%)\end{array}$ & $\begin{array}{c}\text { AvG } \\
\%\end{array}$ \\
\hline Sunday Service & 0.9 & 78.6 & 87.1 & 87.1 & 90.0 & 84.3 & 85 \\
\hline Mid-week Service & 0.8 & 81.4 & 77.1 & 84.3 & 80.0 & 84.3 & 81 \\
\hline Morning cry & 0.7 & 71.4 & 71.4 & 67.1 & 72.9 & 75.7 & 72 \\
\hline Muslim call to prayer & 0.7 & 68.6 & 75.7 & 67.1 & 61.4 & 64.3 & 67 \\
\hline Special programme & 0.6 & 65.7 & 57.4 & 52.9 & 65.7 & 52.4 & 58 \\
\hline Programme rehearsal & 0.6 & 62.9 & 61.4 & 55.7 & 35.7 & 75.7 & 58 \\
\hline Vigil & 0.5 & 61.4 & 51.4 & 54.3 & 35.7 & 51.4 & 51 \\
\hline Subgroup meeting & 0.5 & 32.9 & 57.1 & 41.4 & 35.7 & 57.1 & 45 \\
\hline Room fellowship & 0.4 & 42.9 & 38.6 & 44.3 & 35.7 & 42.9 & 41 \\
\hline Executive meeting & 0.4 & 35.7 & 44.3 & 35.7 & 35.7 & 42.9 & 39 \\
\hline Aggregate mean & 0.6 & & & & & & \\
\hline
\end{tabular}

Source: The authors' fieldwork, 2018

66 Interview with a one-time president of the MSSN, OAU.

67 "Morning cry" is a loose term used to refer to an evangelical strategy of making loud religious preaching or publicity. It carries the word "morning" because it is commonly associated with the morning hours of the day (say, between 5:00 and 6:30 AM), but it is also used to refer to similar activities practised at other hours of daytime.

Interview with the president, UJCM, OAU. 
Furthermore, Table 3.3 reveals that publicity (3.79), morning cry (3.65) and Muslim call to prayer (3.64); Muslim call to prayer (4.20), special programmes (3.76) and publicity (3.73); mid-week service (4.32), Sunday service (4.23) and vigil (4.21) occur most frequently in the morning, afternoon, and night, respectively. However, Muslim call to prayer (3.99) is the most frequent religious activity in the halls across all the times periods. Also, religious activities are most frequent at night (3.48) compared to afternoon (2.76) and morning (2.15). This provides an understanding of the periodicity of the activities. This follows the understanding that being a highly residential institution, ${ }^{69}$ campus lectures officially end by five o'clock in the evening, thus religious activity requiring mass attendance is best scheduled after the official lecture hours. This also informs the kind of activities that occur the most at night - the mid-week service. The logic of conducting mid-week services in the hall of residence is to get maximum attendance, given the distance between the student residential area and the Religion Ground. Expressing this view, the president of the UJCM related that, "By this time of the day, students are already fatigued from the stress of academic activities and most times reluctant (though naturally willing) to walk all the way down to (and from) the Religion Ground for mid-week services. Thus, it is only reasonable for religious bodies to bring the services nearer them, as a way to encourage maximum attendance." 70

Table 3.3: Periodic occurrence of religious activities in the halls

\begin{tabular}{|l|c|c|c|c|}
\hline RELIGIOUS ACTIVITIES & MORNING & AFIERNOON & NIGHT & FREQUENCY INDEX \\
\hline Morning cry & 3.65 & 1.36 & 2.14 & 2.38 \\
\hline Muslim call to prayer & 3.64 & 4.20 & 4.12 & 3.99 \\
\hline Mid-weeks service & 1.64 & 2.31 & 4.32 & 2.76 \\
\hline Sunday service & 2.30 & 3.70 & 4.23 & 3.41 \\
\hline Special programme & 1.45 & 3.76 & 3.41 & 2.87 \\
\hline Room fellowship & 1.43 & 2.08 & 2.71 & 2.07 \\
\hline Vigil & 1.13 & 1.53 & 4.21 & 2.29 \\
\hline Publicity & 3.79 & 3.73 & 3.73 & 3.75 \\
\hline Executive meeting & 1.36 & 2.47 & 2.21 & 2.01 \\
\hline Programme rehearsal & 1.10 & 2.41 & 3.71 & 2.41 \\
\hline Aggregate mean & 2.15 & 2.76 & 3.48 & \\
\hline
\end{tabular}

Source: The authors' fieldwork, 2018

69 A rough estimate reveals that about 70 percent of students reside in University-managed halls of residence. However, this was before the current administration led by professor Eyitope Ogunbodede. Professor Ogunbodede introduced an accommodation policy that witnessed mass exodus of students to off-campus accommodation.

70 Interview with the president, UJCM, OAU. 
Similarly, Table 3.4 depicts that publicity (3.89), morning cry and Muslim call to prayer (3.71), Muslim call to prayer (4.20), special programmes (3.76) and publicity (3.73), mid-week service (4.32), Sunday service (4.23) and vigil (4.21) constitute the greatest sound disturbances for residents in the halls in the morning, afternoon, and night, respectively. Muslim call to prayer (4.01) is the most perceived source of sound disturbance across the three time periods. Furthermore, religious sound disturbances are most severe at night (3.48), compared to afternoon (2.76) and morning (2.17), because sound travels faster at night than any other time in the day. Nights are also naturally for sleeping, which is why most residents find the religious sounds offensive and disturbing at night. Religious sound transgresses between the boundaries of public and private spaces - it is public sound intruding into private space.

Table 3.4: Noise extent of religious activities across time periods

\begin{tabular}{|l|c|c|c|c|}
\hline ReLIGIOUS ACTIVITIES & MORNING & AFTERNOON & NIGHT & NOISE INDEX \\
\hline Morning cry & 3.71 & 1.36 & 2.14 & 2.40 \\
\hline Muslim call to prayer & 3.71 & 4.20 & 4.12 & 4.01 \\
\hline Mid-week Service & 1.69 & 2.31 & 4.32 & 2.77 \\
\hline Sunday Service & 2.30 & 3.70 & 4.23 & 3.41 \\
\hline Special programme & 1.45 & 3.76 & 3.41 & 2.87 \\
\hline Room fellowship & 1.43 & 2.08 & 2.71 & 2.07 \\
\hline Vigil & 1.13 & 1.53 & 4.21 & 2.29 \\
\hline Publicity & 3.83 & 3.73 & 3.73 & 3.76 \\
\hline Executive meeting & 1.36 & 2.47 & 2.21 & 2.01 \\
\hline Programme rehearsal & 1.10 & 2.41 & 3.71 & 2.41 \\
\hline Aggregate mean & 2.17 & 2.76 & 3.48 & \\
\hline
\end{tabular}

\section{Debating the policy implications of the proscription}

The survey responses show that the news of the proscription of sound disturbances was common knowledge amongst the students, with an average of $85 \%$ of residents across the halls indicating awareness, and only $11.7 \%$ and $4.3 \%$, respectively, who were either not sure or ignorant of the action. Still, we went further to ascertain the students' major information sources. This was important to understand the strategic communication of the policy, owing to its influence on the reaction of the students. In this regard, it was discovered that the university circular, announcements made at religious meeting, announcements made over the halls' public address system, and eviction notices posted in spaces where sound disturbances had occurred were the main sources of awareness for the residents, as $85.4 \%, 69.7 \%, 66.9 \%$ and $58 \%$ of respondents, respectively, indicated these sources as their major source of awareness. Only a handful of respondents indicated that they got the information 
about the proscription by witnessing forceful eviction (4.6\%) and disruption of religious activity by a university task force team (6\%). The dean of DSA, the imam of the University Central Mosque and the president of MSSN confirmed that consultative meetings were held with representatives of religious bodies before final evictions were implemented. This indicates that the communication strategies of the university were consultative before and directly after the decision.

Table 3.5: Respondents' source of awareness of the proscription of sound disturbances

\begin{tabular}{|c|c|c|c|c|c|c|c|}
\hline $\begin{array}{l}\text { MAJOR SOURCES } \\
\text { OF AWARENESS }\end{array}$ & MEAN & $\begin{array}{l}\text { PG } \\
(\%)\end{array}$ & $\begin{array}{c}\text { AWOLOWO } \\
(\%)\end{array}$ & $\begin{array}{c}F_{A J U Y I} \\
(\%)\end{array}$ & $\begin{array}{l}\text { MOREMI } \\
(\%)\end{array}$ & $\begin{array}{l}\text { AKINTOLA } \\
(\%)\end{array}$ & $\begin{array}{l}\text { AvE } \\
\%\end{array}$ \\
\hline Awareness (Yes) & 1.72 & 88.6 & 81.4 & 87.1 & 80.0 & 82.9 & 84.0 \\
\hline University circular & 0.85 & 87.1 & 87.1 & 87.1 & 81.4 & 84.3 & 85.4 \\
\hline $\begin{array}{l}\text { Announcement in } \\
\text { religious meeting }\end{array}$ & 0.70 & 72.9 & 64.3 & 75.7 & 72.9 & 62.9 & 69.7 \\
\hline Hall announcement & 0.67 & 68.6 & 64.3 & 71.4 & 67.1 & 62.9 & 66.9 \\
\hline Eviction notice & 0.58 & 51.4 & 61.4 & 70.0 & 60.0 & 47.1 & 58.0 \\
\hline Prior consultations & 0.30 & 31.4 & 24.3 & 32.9 & 32.9 & 28.6 & 30.0 \\
\hline $\begin{array}{l}\text { Non-continuance of } \\
\text { religious activities }\end{array}$ & 0.08 & 5.7 & 1.4 & 20.0 & 8.6 & 2.9 & 7.7 \\
\hline Cessation of sound & 0.07 & 5.7 & 1.4 & 15.7 & 8.6 & 2.9 & 6.9 \\
\hline Room discussions & 0.06 & 5.7 & 1.4 & 12.9 & 8.6 & 2.9 & 6.3 \\
\hline $\begin{array}{l}\text { Witnessing of } \\
\text { activity disruption }\end{array}$ & 0.06 & 5.7 & 1.4 & 11.4 & 8.6 & 2.9 & 6.0 \\
\hline $\begin{array}{l}\text { Witnessing of } \\
\text { forced eviction }\end{array}$ & 0.05 & 5.7 & 0.0 & 10.0 & 8.6 & 2.9 & 4.6 \\
\hline Aggregate mean & 0.34 & 33.99 & 30.70 & 40.71 & 35.73 & 30.03 & \\
\hline
\end{tabular}

Despite the effective nature of the policy decision making and implementation strategy, the aftermath of the proscription was greeted with dissenting voices. In Table 3.5, respondents were polarised about their opinion of the action. This polarisation can be represented as a continuum with two radical extreme perceptions - one extreme projects the idea that the decision of the university management was aimed at restricting freedom of religion, and the other projects the understanding that the action is an effective way to moderate the dangerous tide of religious fanaticism and, as such, encourages freedom from religion. Furthermore, the mean scores of perception in Table 3.6 depict, on the one hand, that the proscription represents religious de-participation (3.76), religious bias (3.69), end-time sign (3.76) and restriction of religious freedom (3.70). On the other hand, it is perceived as the right action to stem the tide of religious fanaticism (3.62), unify the already proliferating religious denominations (3.50) and encourage academic scholarship (3.48). 
Table 3.6: Residents' perception of proscription of religious activities

\begin{tabular}{|c|c|c|c|c|c|c|}
\hline Perceptions & MEAN & $\begin{array}{c}\text { StRONGLY } \\
\text { DisAGREE } \\
(\%)\end{array}$ & $\begin{array}{c}\text { DISAGREE } \\
(\%)\end{array}$ & $\begin{array}{c}\text { Neutral } \\
(\%)\end{array}$ & $\begin{array}{c}\text { AGREE } \\
(\%)\end{array}$ & $\begin{array}{c}\text { StRONGLY } \\
\text { AGREE } \\
(\%)\end{array}$ \\
\hline De-participation & 3.76 & 6.0 & 17.1 & 9.1 & 30.3 & 37.4 \\
\hline Bias & 3.69 & 7.1 & 16.9 & 10.0 & 32.0 & 34.0 \\
\hline End-time sign & 3.76 & 11.4 & 2.6 & 18.3 & 34.0 & 33.7 \\
\hline $\begin{array}{l}\text { Restriction of } \\
\text { religious freedom }\end{array}$ & 3.70 & 6.0 & 16.9 & 8.6 & 38.3 & 30.3 \\
\hline Fractionalisation & 3.41 & 22.9 & 5.4 & 8.6 & 33.7 & 29.4 \\
\hline Disintegrate & 3.64 & 6.0 & 16.9 & 11.1 & 39.1 & 26.9 \\
\hline Disunite & 3.60 & 6.0 & 16.9 & 14.0 & 37.4 & 25.7 \\
\hline Secularism & 3.13 & 8.6 & 27.4 & 23.7 & 23.1 & 17.1 \\
\hline $\begin{array}{l}\text { Academic } \\
\text { performance }\end{array}$ & 2.75 & 22.9 & 28.0 & 23.2 & 2.3 & 23.1 \\
\hline Defiance & 3.48 & 23.1 & 3.1 & 8.6 & 32.6 & 32.6 \\
\hline Unify & 3.50 & 22.9 & 2.9 & 8.6 & 33.1 & 32.6 \\
\hline Fanaticism & 3.62 & 21.1 & 4.6 & 8.6 & 22.3 & 43.4 \\
\hline
\end{tabular}

Re-negotiating education space between religion and sound: freedom of, from or for religion?

It is clear from these findings that, instead of bringing an end to the contestation on space and religious freedom, the proscription of sound disturbances further polarised the perception of the students and other university stakeholders. Underlining these opposing perceptions is, on the one hand, the difference in appropriation of space and, on the other hand, the remarkable similarity in the consequential sound scape. This is to say that while religious activities constitute some sound disturbance, in actual fact, other forms of student social interactions constitute greater sound disturbance. For instance, during the weekends (starting from Friday evenings to Sunday evenings), apart from the musicals that are blared over the loud speaker in the mood of weekend relaxation (which often spans almost the length of the whole day until around eleven o'clock at night), sounds emanating from the hall common rooms as a result of students watching Saturday and Sunday professional football league matches also constitute significant sound disturbances. Thus, sound, whether religious or non-religious, and much like religion itself, is an important sociocultural resource through with the people keep touch with their lived realities. In a pluralistic environment, such as an educational space, it "is never an objective or neutral phenomenon". ${ }^{71}$

71 De Witte M. 2008. “Accra's Sounds and Sacred Spaces”, International Journal of Urban and Regional Research 32(3):690-709. 
In light of this, we argue that the reason neither the model of freedom of religion nor freedom from religion, as provided for in OAU student handbook and more generally in the Nigerian Constitution, can provide a plausible compromise for the management of expression of religious freedom, is because each is hinged on the notion that religion is a private affair. Contrary to this assumption, everyday lived realities in the country continue to show that, for Nigerians, religion is beyond a private affair and much more of a public affair. For an average Nigerian, religion represents the embodiment of his or her person and everyday lived reality. As such, the positive value of religion should be recognised and reflected in our regulations.

With this in mind, we here advocate for the model of freedom for religion. Though a scarce expression in the scholarly discourse of religious freedom, it is not entirely new, as some scholars have begun to identify it as a veritable tool for a sustainable compromise in religious freedom debates in plural societies. ${ }^{72}$ The challenge is that we will continue to witness the divisive and differential character of religion in educational spaces, because while the freedom from religion model projects religion as a negative phenomenon that must be separated from public space, the freedom of religion model maintains a neutral stance thereby engendering regulatory contradictions. It is our argument then that we should instead recognise the value and importance of religion in the educational space and treat religion positively, so that we can then formulate appropriate policies to facilitate the smooth operation of religious freedom in education space.

Our contention is that freedom should be in the service of, or used to facilitate, religion. This will not be possible if religion is not seen as a positive aspect of not just private life, but also public life. It is important to state, however that we are not calling for government or other authorities to begin to demand religious observances from the people, but rather that they should commit to a more positive secularism. ${ }^{73}$ United States law and religion scholar Richard Garnett recommends that "government under this approach, will not only refrain from discriminating against religion, it will take special care to accommodate and facilitate it - though always in a way that respects the distinction between "church" and "state" and the liberty of individual conscience". ${ }^{74}$ The regulatory framework and the proscription policy do not reflect this understanding and, as such, they are out of tune with the lived reality of the students.

72 See Garnett RW. 2010. "Positive Secularism and the American Model of Religious Liberty", Engage 11(1):126-127; and Scharffs, Moaz and Woolley, "Freedom of/for/from/within Religion: Conceptually Inseparable Right?".

Garnett, "Positive Secularism and the American Model of Religious Liberty", 127.

Garnett, "Positive Secularism and the American Model of Religious Liberty", 127. 


\section{CONCLUSION}

This chapter has examined the challenges involved in managing religious expression in education spaces. We used the case of the proscription of religious activities in students' halls of residence at Obafemi Awolowo University to explore how religious sound disturbance is negotiating the boundary of religious freedom in a higher education institution. In the process, we have brought to the fore the contention amongst freedom of, from and for religion. The contentions over these terms underlie the varied opinions of university stakeholders about the appropriation, periodicity and temporality of the education spaces. The contradiction inherent in the regulatory frameworks also contributes significantly to these contestations.

We have equally shown that the contradiction in regulatory frameworks stem mainly from the desire to both adhere to freedom of religion and freedom from religion, the result of which has been an impossibility. As such, this chapter advances the argument that, given that religion is a positive sociocultural resource through which the people negotiate their lived reality, it is important to go beyond a neutral and negative attitude that freedom of and from religion portends and grant more significant status to religion in regulatory frameworks. It is only then that harmonious coexistence can be achievable. The university is already taking a step in this direction by allocating portions of lands to duly registered religious associations. This is a good intervention, which helps to exemplify our proposition of freedom for religion model. While this initiative is encouraged, due diligence must be taken to avoid the allowance of partiality in its implementation, as this will reintroduce the contradiction which it seeks to eliminate in the first place.

Similarly, it is important to strengthen the extant regulations of the university with respect to sound disturbances in general and religious sound in particular. In this regard, we have equally argued that the regulations must seek to reflect the spirit of freedom for religion and not freedom of religion. To achieve this, first, it needs to be explicitly stated what the general permissible noise threshold is. At present, the only regulation relating to the guideline of noise within the university halls of residence gives consideration only to "noisy parties". It is either an oversight of the regulation or an outright disallowance for religious sound. While state and national regulations have set a threshold of 45 decibels in the day and 35 decibels at night for public spaces, ${ }^{75}$ it is necessary either to restate this national threshold in the university regulations or to modify them further. In this way, there will be due recognition of the positive role of religion in education. This follows the same logic of speed limit regulations. Despite the fact that there are speed limit regulations for highways and off campus roads, yet the university management went ahead to institute speed limits on the campus roads as well. As such, it is important to state the threshold of sound allowed within the halls of residence and other public spaces within the university.

75 National Environmental (Noise and Standards Control) Regulations. 2009. First Schedule. 
Finally, to reflect the spirit of freedom for religion, it is important to give consideration to some religious activities, given that the religious activities do not contribute to sound disturbance equally. Thus, contrary to the outright proscription of religious activities, it is important to give allowance for religious activities that do not exceed the permissible sound threshold allowed for the halls of residence. In this way, the regulation will appear reasonable without negating the lived realities of the students while also taking cognisance of the health dimension of sound menace. 